\title{
Why did a U.S. secondary school district retain teacher-librarians in a time of economic crisis? A case study
}

\author{
Ann Dutton Ewbank \\ Arizona State University, Fletcher Library, P.O. Box 37100, Phoenix, AZ 85069-7100 USA. Email ann.ewbank@asu.edu
}

\begin{abstract}
The number of U.S. teacher-librarians has greatly diminished despite advocacy efforts by stakeholders. This case study investigated the factors that led governing board members in a mid-sized urban high school district to retain certified teacher-librarian positions despite a major economic crisis. Themes constructed through the analysis were: stakeholder involvement; transparency in communication; trust between district leadership and the governing board; a commitment to the district's core values; and the value placed on the school library program by the district's stakeholders. Future research should investigate school districts' decision-making processes in the retention of teacher-librarian positions during economic crises.
\end{abstract}

\section{Introduction}

The purpose of this study is to investigate the factors that led governing board members in a large urban high school district to retain certified teacher-librarians despite the major economic crisis of 2009. In the past several years, the number of teacher-librarians has greatly diminished. Currently only $60 \%$ of K-12 public schools in the United States employ a state certified teacher-librarian (American Libraries, 2007). In Arizona, the location of the study, only $38 \%$ of public schools are staffed with a certified teacher-librarian (Kossan, 2008).

The Brookdale Union High School District ${ }^{1}$, a mid-size urban district with 15,000 students in grades 9-12, stands out from other Arizona school districts. Brookdale chose to retain certified teacher-librarians in its nine high schools, despite a major economic crisis in which approximately $10 \%$ of its operating expenses were reduced. In order to fulfill mandated budget reductions, other Arizona districts either eliminated or reduced certified teacherlibrarian positions. Some districts replaced certified teacher-librarians with paraprofessionals in order to reduce salary costs, and others eliminated library personnel completely, relying on teachers and volunteers to manage library spaces in schools. The case study of Brookdale provides an understanding of the decision-making process used to retain teacher-librarian positions, sheds light on possible future decision-making in the district and offers implications for future research.

\section{Review of the literature}

Advocacy for public school library media programs in the U.S. has gained attention in recent years as a result of drastic eliminations in teacher-librarian positions and funding reductions in schools and school districts. These eliminations prompted the American Library Association (ALA) to appoint a special Task Force on the Status of School Libraries (ALA, 2005). Since the adoption of its report in 2006, ALA launched several initiatives to advocate for a state-certified librarian in every U.S. public school. The American Association of Teacherlibrarians (AASL) created an Advocacy Toolkit, several resolutions on various aspects of school libraries were adopted by the ALA's policy-making Council, and responses to position and funding elimination were developed. ALA and AASL's most ambitious school library advocacy activity to date is the promotion of the SKILLs Act, which amends the U.S. No Child Left Behind Act to require school districts, to the extent feasible, to employ one state-certified librarian in every school library (AASL, 2008).

Despite the above initiatives attracting much attention, school district decision-makers across the nation continue to eliminate teacher-librarian positions as part of cost-saving measures. The unevenness of decisions to retain or

\footnotetext{
${ }^{1}$ All descriptive locations are pseudonyms.

(C) 2010 IASL, SLAQ and therein by the authors. Diversity Challenge Resilience: School Libraries in Action Proceedings of the $12^{\text {th }}$ Biennial School Library Association of Queensland, the $39^{\text {th }}$ International Association of School Librarianship Annual Conference incorporating the $14^{\text {th }}$ International Forum on Research in School Librarianship, Brisbane QLD Australia, 27 September - 1 October 2010.
} 
eliminate is perplexing; little is understood about why some school districts choose to retain teacher-librarian positions while others do not.

While advocacy is clearly necessary, advocacy campaigns do not always influence board members to retain teacher-librarians. From Medina, Washington (Whelan, 2009) to Mesa, Arizona (Whelan, 2008) teacherlibrarian advocacy consists of strategies and techniques for advocacy (e.g., Bush, 2007; Hainer, 2005; Leverett, 2001; Schuckett,2005; Williams, 2006) using evidence-based practice as an advocacy tool (Asselin, 2006;Braxton, 2003; Loertscher \& Todd, 2003; Logan, 2006; Todd, 2003, 2006, 2008a, 2008b) and reports of successful advocacy initiatives (e.g., Burris, 2006; Giambra, 1998; Kenney, 2008; Russell, 2004). The researcher found no empirical studies specifically describing why or how school district decision-makers choose to retain or eliminate teacher-librarian positions. Therefore, the study of Brookdale Union High School District's decisionmaking process in retaining teacher-librarians addresses a gap in the literature in school library advocacy.

\section{Methodology}

The researcher used a descriptive case study approach (Yin, 2008). The descriptive case study approach is ideal for uncovering the complex factors that led the Brookdale Union High School District to retain teacher-librarian positions in an economic crisis. Yin describes four applications of a descriptive case study. First, the methodology can explain complex causal links in real-life decisions. Second, a case study can describe the reallife context in which the decision has occurred. Third, it can describe the decision itself. Finally, descriptive case studies can explore those situations in which the decision being evaluated has no clear set of outcomes. The descriptive case study method was appropriate to examine the multiple perspectives of the board, district personnel, and teacher-librarians. The method was also appropriate for examining Brookdale in context. While the outcomes of reducing the budget and retaining teacher-librarians were clear, the circumstances surrounding these decisions was complex and involved multiple stakeholders, thus affirming the appropriateness of the case study methodology.

To ensure construct validity (Yin, 2008) and data source triangulation (Denzin, 1984) multiple sources of evidence were collected and analyzed. These sources included financial reports, governing board minutes, and district documents including the district's core values statement and an explanation of the district's Learning System (see Figure 1). Additionally, using a semi-structured format, the researcher interviewed five school district stakeholders: the superintendent, the administrator of finance, a governing board member, an assistant principal, and a teacher-librarian. Participants were given copies of the interview questions. These questions guided the interviews but interviews were not limited to the written questions. Interviews were audio recorded and transcribed. The researcher analyzed the transcripts against each other and the other data sources to determine case study themes. Prior to initiating research, the study was reviewed by the Arizona State University Human Subjects Review Board, and was classified as exempt under U.S. federal law 45 CFR 46.101(b).

\section{Findings}

Brookdale Union High School District is a mid-sized urban school district in Arizona, USA. The 97 year-old district serves 15,000 students through nine high schools and two alternative programs. One Brookdale high school is consistently recognized as one of the country's top 100 high schools in U.S. News and World Report. The school district is guided by four strategic goals:

1. Ensure outstanding student academic achievement

2. Manage all fiscal resources wisely

3. Maintain effective, positive community relations

4. Attract and retain a highly qualified faculty and staff

(C) 2010 IASL, SLAQ and therein by the authors. Diversity Challenge Resilience: School Libraries in Action Proceedings of the $12^{\text {th }}$ Biennial School Library Association of Queensland, the $39^{\text {th }}$ International Association of School Librarianship Annual Conference incorporating the $14^{\text {th }}$ International Forum on Research in School Librarianship, Brisbane QLD Australia, 27 September - 1 October 2010. 
In late 2008, the Arizona economy began to take a turn for the worse. Unemployment began rising, and new housing, which is the cornerstone of the Arizona economy, came to a screeching halt. As a result of the economic turndown, Brookdale Union High School District administrators expected deep reductions in state funding, as did all Arizona public education decision-makers. Approximately $48 \%$ of the Arizona state budget supports K-12 education (Arizona Joint Legislative Budget Council, 2010). As the state's economy began to falter, district leaders knew that at some point their budget would be impacted. They began planning to tackle the crisis in anticipation of being asked to return money to the state in order to resolve a mid-year deficit.

In January 2009 , the district was asked to return $\$ 2$ million to the state from its original allotment, which amounted to 3-4\% of the total district budget. However, at that time, $85 \%$ of the district budget was encumbered in contractual salaries, so the cuts had to come from the remaining $15 \%$ of the budget, which consisted of operating expenses such as utilities, transportation and supplies and soft capital such as carpet replacement, library books, and vehicles.

In order to determine and prioritize potential mid-year reductions, the leadership reached out to stakeholders. Each member of the district leadership team, whom Superintendent Dr. Jane Jones ${ }^{2}$ refers to as "the cabinet" visited a school and spoke with the staff there. These district leaders explained the reality of the situation to the school staff, and warned that the coming fiscal year would be even worse. At the school sites staff brainstormed ways to reduce operating expenses. Ultimately the district returned the $\$ 2$ million to the state through cuts to operating expenses and soft capital and did not eliminate any non-contractual personnel. One of the largest savings came from reduction of energy consumption at the school sites. The district achieved this through eliminating small appliances in areas other than staff lounges and halting the use of televisions as classroom clocks, among other measures. The district-wide commitment to energy reduction was so successful that the local power company visited several school sites to ensure that the meters were not broken.

However, the 2008-2009 budget reductions were only the tip of the iceberg. Like all school districts in Arizona, Brookdale expected an even smaller budget allocation in 2009-2010. In a communication to district residents in March 2009, Superintendent Jones outlined the potential consequences of current and future budget reductions. She stated,

With the passage of the most recent state budget adjustments, the Brookdale Union High School District is faced with cutting at least $\$ 1.8$ million from its current operating and capital budgets. Like many of our neighboring districts in the [area], we have diligently worked to continue to provide a quality education to every student while maximizing the use of our resources. The district continues to manage its finances with great care. We have not filled positions, purchased equipment or supplies that were not essential and we have conserved energy at every point possible on a daily basis. As we look to the future, we share the most serious concern of all school districts related to what the state legislature may propose as cuts to next year's budget. The Brookdale Union High School District, like our neighboring districts, will be faced with massive cuts if current proposals are enacted. These cuts, which could exceed $\$ 13$ million for our district, will significantly increase class size, potentially cut programs like band, athletics and the arts and cause the district to reduce its staff, including teachers, thus adding to our community's unemployment challenges.

The district leadership knew that the anticipated budget reduction, possibly $\$ 13$ million, in the forthcoming fiscal year would force the district to eliminate positions. Superintendent Jones stated, "If $85 \%$ of [the budget is] tied up, and you've got to cut $\$ 13$ million, and you can't not provide transportation, and you can't not pay your

\footnotetext{
${ }^{2}$ All names are pseudonyms.

(C) 2010 IASL, SLAQ and therein by the authors. Diversity Challenge Resilience: School Libraries in Action Proceedings of the $12^{\text {th }}$ Biennial School Library Association of Queensland, the $39^{\text {th }}$ International Association of School Librarianship Annual Conference incorporating the $14^{\text {th }}$ International Forum on Research in School Librarianship, Brisbane QLD Australia, 27 September - 1 October 2010.
} 
electric bill, and you can't not provide some school supplies...it doesn't take long to figure out that you can't get to $\$ 13$ million without touching personnel costs."

Once again, in early 2009 district leadership reached out to stakeholders in order to determine how and in what order to reduce costs for the upcoming fiscal year. Superintendent Jones and her leadership cabinet held meetings at each of the district's nine schools, outlining the potential budget scenario, and asking for input from staff. Dr. Jones explained the mechanism for gathering stakeholder input:

Based on the philosophy that people who are affected by a decision should have some input into the decision, we went back out to the schools, and worked with every staff member, and I do mean every staff member: the maintenance department; the clerical staff; instructional aides; teachers; administrators. Everybody on the campus had the opportunity to meet in groups, to learn more about what was happening with the budget, and then to provide input into what should we do...We gave out this list that said, "Here's what we spend money on. Here [are] your choices. Look at this list, and see if you can't develop a list of \$13 million worth of cuts," which was simultaneously enlightening and empowering to our staff.

District leadership provided a caveat for input about potential budget reductions. Leadership would do everything in its power to protect the Learning System. The district's Learning System (Figure 1) is a continuous cycle of curriculum, instruction, and assessment.

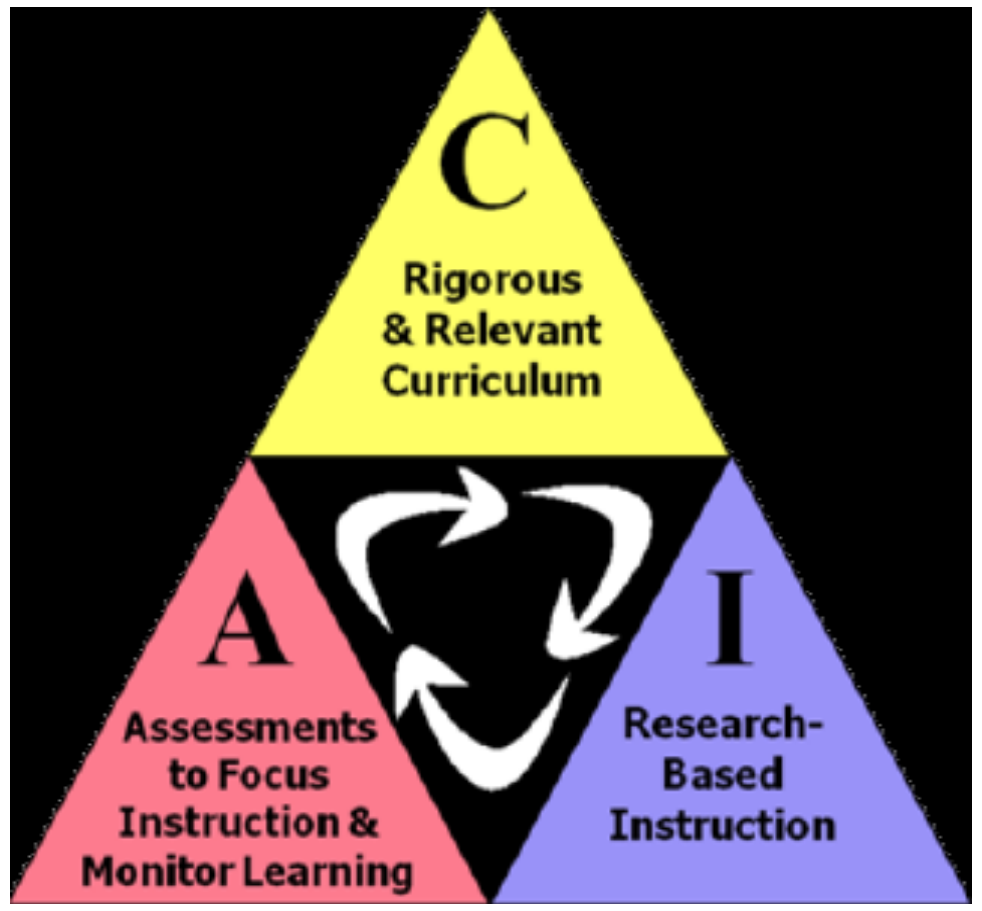

Figure 1. Brookdale Union High School District learning system

A district presentation provides the context and importance of the Learning System:

The Learning System is the blueprint to our success. The Curriculum gives us our "what" we are teaching; the Instruction gives us the "how" we teach; and the Assessment gives us our "checkpoint" to

(C) 2010 IASL, SLAQ and therein by the authors. Diversity Challenge Resilience: School Libraries in Action Proceedings of the $12^{\text {th }}$ Biennial School Library Association of Queensland, the $39^{\text {th }}$ International Association of School Librarianship Annual Conference incorporating the $14^{\text {th }}$ International Forum on Research in School Librarianship, Brisbane QLD Australia, 27 September - 1 October 2010 . 
make sure that learning is taking place and gives us a chance to fill in any gaps that are evident. Just like the pieces of a puzzle, the learning system will not give a complete picture of success when looked at separately... One component of the learning system is no more important than the other. They are all aligned to the state and national academic standards and are all used to help us strive to make continuous improvement year after year. We are always in a constant effort to improve each aspect of the learning system so that we can provide the best education possible to all students.

The Learning System represents a very important focal point in the district. Developed and refined over the last forty years, each person interviewed for this study mentioned the learning system as a framework for how the district would address and prioritize eliminations. Dr. Jones noted that by protecting the Learning System, the district would attempt to make cuts as far away from the classroom as possible.

After the schools met in small groups to determine possible budget reductions, the suggestions were forwarded to the cabinet for analysis. Dr. Jones estimated that the cabinet spent over 200 hours collectively analyzing, prioritizing and adjusting what came to be referred to as "the list." Simultaneously, the cabinet began a series of conversations with the governing board about the items on the list. The list amounted to a total of $\$ 13$ million in reductions, anticipating that this number was the maximum that the district would be required to cut. However, even in theory, the development of the list was difficult and could not be prioritized in a way that spared all positions. Dr. Jones explained,

We... prayed every day that we weren't going to actually have to get to $\$ 13$ million. Because to get to the things on the bottom of the list that got you from, for example, $\$ 10$ million to $\$ 13$ million, were going to be very difficult and painful cuts...The things at the top of the list... we figured we could cut $\$ 1$ million and it wouldn't be too bad. By the time you got to $\$ 10$ million, it was painful. About halfway through the list, it was not possible not to cut positions. Then you have to think, "Okay...if you have to do it, which positions can you cut?

In addition to the prioritized list, district leaders attempted to preserve resources by moving expenses into other budget allocation areas. For example, they identified items that could be paid for from federal funds such as Title I (which provides monies to improve academic achievement of the economically disadvantaged), rather than state allocation. When the state budget was passed on the eve of the new fiscal year, Brookdale Union High School District was directed to eliminate \$8.5 million from its total operating budget for the 2009-2010 school year. The reductions were made using the prioritized list that was developed over the previous year.

To fulfill the reductions, the district eliminated 120 positions, primarily classified (non-teaching) staff. Included in the classified staff reduction were the library media center aides, leaving the libraries staffed with one certified teacher-librarian and no paraprofessional assistance. There were a number of certified teachers who also lost positions, retired from the district and employed by a lease-back company. The remaining budget reductions came from soft capital, normal employee attrition and retirements. Another impact on the district's libraries was a reduction in the book and electronic resource budget at each school.

While the library programs were impacted at each school, the certified librarian positions remained. The rationale for retaining the certified librarian positions was described by Dr. Jones:

We were looking everywhere. Every position. So yes, we looked at [certified librarian positions] in general terms, just as we looked at athletics... So we get to the media center and we think, "Okay, what's possible here?" We had a reasonably short debate about [whether] there is room for some elimination here? Yes. Then conversation about, okay, which should it be? Because at that point we began to hear news from other districts that they were eliminating [certified librarian] positions...there were schools

(C) 2010 IASL, SLAQ and therein by the authors. Diversity Challenge Resilience: School Libraries in Action Proceedings of the $12^{\text {th }}$ Biennial School Library Association of Queensland, the $39^{\text {th }}$ International Association of School Librarianship Annual Conference incorporating the $14^{\text {th }}$ International Forum on Research in School Librarianship, Brisbane QLD Australia, 27 September - 1 October 2010. 
across the state that made the decision to eliminate the certified position, and keep the support-staff position. It didn't take us long to really come to the decision that we could probably live without the support-staff position, but that keeping the certified position was important to us. It was important for a variety of reasons...It seems pretty counter-intuitive, if one of your district initiatives is working on literacy, to eliminate the position that plays a key role in campus-wide literacy...And we worked really hard to help everybody understand that literacy isn't what happens in your English class. End of conversation. Literacy is what happens 24 hours of your day... So we knew we had to keep somebody in [the library], and...it didn't really take us very long to figure out that the certified position was the one position with the level of expertise that we really needed to have.

In summary, while the school district was faced with significant budget reductions, a well-crafted prioritization process with a focus on the core values and mission of the school district, allowed the governing board to make informed choices while maintaining instructional integrity. The following discussion provides insight on the themes constructed through the analysis of stakeholder interviews and district documents.

\section{Discussion}

The norms of decision making are influenced by the relationship of the district's values and organizational structure (Hinings \& Greenwood, 1987). Educational organizations share many common cultural practices and tacit decision-making patterns (Greenwood \& Hinings, 1993; Patterson, Koenigs, Mohn, \& Rasmussen, 2006). Using research on school district organizational decision-making to provide a framework, the researcher constructed several values-oriented themes that influenced the decision to retain certified teacher-librarians at each school by analyzing interviews with the district superintendent, the administrator of finance, a governing board member, an assistant principal and a teacher-librarian in addition to district documents.

In the Brookdale Union High School District, these values-oriented themes around decision-making include stakeholder involvement; transparency in communication; trust between district leadership and the governing board; a commitment to the district's core values, including the learning system; and the value placed on the school library program by the district's stakeholders. Each theme is discussed in the following sections.

\section{Stakeholder involvement}

A cornerstone of the district's decision to retain teacher-librarians was stakeholder involvement in the decision making process. While the decisions for budget reductions were the ultimate responsibility of the governing board in consultation with the district administration, a carefully crafted process that included multiple stakeholders at various levels was carried out over a period of time. Governing board member Pat Reed described the process in this exchange:

Researcher: So what I'm hearing is that the community was involved, that it just wasn't made at [the administrative] level. You got feedback and input.

Reed: $\quad$ Yes. It was principals, and it was teachers, and the [teachers' association] had a big say as well.

Administrator of Finance Jerry Hinter also discussed stakeholder involvement in the process. Additionally he noted that there was agreement on the priority order of the eliminations:

We began a process where we went around to all nine of our schools and gathered input from faculty at each of the schools to hear what their feelings were about where cuts should be made...We did get input from everybody, and ideas. It was interesting, when you go around and talk to that many people, how

(C) 2010 IASL, SLAQ and therein by the authors. Diversity Challenge Resilience: School Libraries in Action Proceedings of the $12^{\text {th }}$ Biennial School Library Association of Queensland, the $39^{\text {th }}$ International Association of School Librarianship Annual Conference incorporating the $14^{\text {th }}$ International Forum on Research in School Librarianship, Brisbane QLD Australia, 27 September - 1 October 2010. 
similar a lot of the items lined up. There really weren't huge differences... generally everybody was of the same sense in terms of protecting classrooms and the integrity of the [learning] system.

Furthermore, Dr. Jones described the stakeholder involvement process as unusual for a school district:

There are other superintendents who would tell you that I was crazy to go out and ask every employee for their input... It's not standard... I didn't hear any other superintendent talk about going out for that level of input. Certainly, you would go to your principals. Obviously, you'd go to your governing board. They have ways to get input. Superintendents don't make decisions like this in a vacuum. But the fact that the custodian had the chance to weigh in on the school budget -and that we would be that transparent with what things cost - is pretty unusual.

All participants agreed that the process for gathering input for making decisions about budget reductions involved stakeholders at multiple levels. However, no participants reported that parents or teachers were involved in the process. Lack of parent and student involvement in budget decisions is not out of the ordinary. In a review of the literature on parent involvement, Cotton and Wikelund (1989) found that school administrators were reluctant to involve parents in matters of governance and budget. Fielding (2001) described student involvement as a phenomenon where educators and parents speak too readily on their behalf without their consultation. Although parent and student involvement were not reported by the participants, the decisionmaking process in Brookdale can still be characterized with a high degree of stakeholder involvement.

\section{Transparency in communication}

Interviewees consistently characterized the process of determining budget reductions as transparent. In an interview with Lauren Doss, librarian, and Sandi Andrews, assistant principal, both remarked that they felt that the process was transparent:

Lauren: Yes. I think communication was very important and involvement, just in that buy-in of "we're not sending this down to you. And we want you to be a part of this process..."

Sandi: Well, everybody's opinion counts. "We want to hear what you have to say, we might not be able to use it all, but we're going to listen." I think everybody was allowed an opportunity to speak if chosen to do so.

Administrator of finance Jerry Hinter also characterized the process as transparent:

It was very transparent. I don't know how it could be more transparent than the people being able to see what was going on, because it was their time, their investment that was leading to the results...my opinion is that everybody felt they had opportunity to be heard, and were heard.

However, Dr. Jones noted that the transparent process was not without risks, yet has the potential to create an environment where stakeholders discuss value and priorities:

Also, the risk is that it begins in a sort of fearful environment. It potentially pits employees against each other. "Let's see. I think my job is really important, but I don't think that job's important, and, oh my god, we pay that much for that?" So it really begins to provoke some conversations about value.

Transparency is an important value in that organizations talk increasingly about the necessity of communicating with stakeholders and the community (van Riel, 2000). Organizations such as school districts "make important

(C) 2010 IASL, SLAQ and therein by the authors. Diversity Challenge Resilience: School Libraries in Action Proceedings of the $12^{\text {th }}$ Biennial School Library Association of Queensland, the $39^{\text {th }}$ International Association of School Librarianship Annual Conference incorporating the $14^{\text {th }}$ International Forum on Research in School Librarianship, Brisbane QLD Australia, 27 September - 1 October 2010. 
information about their practices available to external audiences (Christensen, 2002, p. 166)." One can argue that during internal shared decision-making processes the same principle applies.

\section{Trust between district leadership and the governing board}

Another theme found in the interviews was the level of trust between the governing board and the district's leadership. The interviews reveal a strong level of trust between the superintendent, district staff, and the governing board. Board member Pat Reed described a high level of trust with district leadership. She stated:

The fortunate thing about our school board is we're not trying to say, "Oh, we're school board, so we say - and we're [going to] do this."...We want recommendations from the expert. So if you ask all these experts, "What's your advice? Give us your expert advice." Then we listen, and we weigh what we think and what we know with what they're telling us, and that's how decisions really get made... Our cabinet is very professional, and knowledgeable...I'm just really impressed with the staff at this district, as far as the cabinet. They're very, very intelligent and knowledgeable...Thank God, because that's what you want.

Dr. Jones also noted the high level of trust in district leadership, particularly in the administrator of finance, Jerry Hinter. She stated:

The governing board knows Jerry very well, and I think you will find, if you talk to governing board members, they will also compliment Jerry's [ability] - just the idea that we had somebody competent in that area, that we knew we could trust his advice and his analysis... But as you will find out when you talk to him, Jerry Hinter is masterful at his knowledge of the intricacies of the budget. He's the most brilliant school finance guy I've ever met, and I am incredibly blessed, as the superintendent, to have somebody who is that knowledgeable. Jerry has also been with the district for more than two decades, so he's been through fluctuations. He understands, as best we can most of the time, the thinking of the legislature, and where they might be going in those kinds of things.

The relationship between the school board and school district personnel can impact decision-making. There is a significant body of literature that indicates that the relationship between the district superintendent and the school board significantly impacts the quality of education and student academic success (Peterson and Williams, 2005). In terms of superintendent recommended action items, favorable board voting is related to the superintendent's trustworthiness, expertise, and compatibility with the board president (Petersen \& Short, 2001). The interviews of Superintendent Jones, Director of Finance Hinter and Governing Board member Reed indicated a high level of trust between the district leadership and the governing board.

\section{Commitment to district's core values}

In each interview, participants noted that the district's core values, especially its Learning System, were integral to the process of prioritizing reductions. Dr. Jones noted:

The district's learning system is who we are. We'd give away a lot of things before we'd do that. It is something that the district has worked hard, over the last 40 years, almost, to develop. It is something that sets us apart. That also gives us some strategic focus...The quickest way for me to lose my job would be to lose my focus on the learning system, as the superintendent. If the governing board ever lost faith that I understood the importance of that learning system, they'd be looking for a new superintendent... it's clearly the strategic engine that drives this district. It is what we believe sets us

(C) 2010 IASL, SLAQ and therein by the authors. Diversity Challenge Resilience: School Libraries in Action Proceedings of the $12^{\text {th }}$ Biennial School Library Association of Queensland, the $39^{\text {th }}$ International Association of School Librarianship Annual Conference incorporating the $14^{\text {th }}$ International Forum on Research in School Librarianship, Brisbane QLD Australia, 27 September - 1 October 2010. 
apart, and it is, quite frankly, that focus that allows us to achieve the kind of results we get with the kids that we serve.

Jerry Hinter, administrator of finance, also noted the central focus on the Learning System:

I always go back to the learning system; okay, what's the impact on the learning system if we don't' have that position versus the other position. And that becomes an important...variable in trying to decide what [we are] going to cut.

Board member Pat Reed saw the importance of the learning system in determining priorities and reductions. She also explained the relationship between the learning system and the decision to retain teacher-librarians:

I think because we have our learning system, our core values, and we have, running across the curriculum, it's a priority in our district. The media center (which is how we refer to libraries) is integral to every area, and that's that. So how can you cut the teacher-librarians?

Assistant principal Sandi Andrews also commented on the learning system as integral to the budget process. She stated, "I think that there's no doubt that [the learning system] influences budget...our district for lack of a better word, lives and dies by that and how they all effect each other." Finally, librarian Lauren Doss noted how the learning system provides a framework in which to focus on students. She explained, "I would say [the learning system] has to [be a priority] because that is what we hear, what we live. I just always think that students are the priority. That is what I think and what I hear so frequently, 'What's going to be the best for the kids?"”

The district's Learning System is an indication of the development of shared values over a period of time. Each participant indicated the central place that the Learning System has in driving the mission and vision of the district. The development of the Learning System as a set of core values can be explained through purposing, defined as "that continuous stream of actions by an organization's formal leadership which has the effect of inducing clarity, consensus and commitment regarding the organization's basic purposes" (Vaill, 1984, p. 91). The district leadership, over time, successfully purposed the Learning System as a focal set of core values for district stakeholders.

\section{Value of the school library program}

Each participant noted the value of the school library program as it relates to the core mission of the school district as a reason for retaining certified teacher-librarians during the time of determining budget reductions. Administrator of finance Jerry Hinter acknowledged the role of the librarian as an expert guide in using technology for research and promoting critical thinking:

With the advent of technology our media centers are much better areas than what ten years ago you would have seen as a library... When students do research, there is so much information out there for them to access. They're in to a lot more critical thinking than they used to have to do to try to arrive at a conclusion or to draw up their paper. They're a big contributor to the schools.

Superintendent Jane Jones noted the librarian's role in school wide curriculum integration and literacy promotion. She also commented on the librarian as teacher:

They bring a unique expertise to providing services to students... if we want to make sure that literacy is seen as everyone's responsibility, then the media center's director plays a unique role in doing that because..they work with teachers from across the curriculum. They have a unique perspective on what

(C) 2010 IASL, SLAQ and therein by the authors. Diversity Challenge Resilience: School Libraries in Action Proceedings of the $12^{\text {th }}$ Biennial School Library Association of Queensland, the $39^{\text {th }}$ International Association of School Librarianship Annual Conference incorporating the $14^{\text {th }}$ International Forum on Research in School Librarianship, Brisbane QLD Australia, 27 September - 1 October 2010. 
people are doing... That's their expertise, how to make those linkages. They've also worked really hard to help kids just read more. We believe that part of the development of good readers is literally just the experience and practice of reading...They deliver instruction in unique ways... The decision was focused on doing everything we could to make sure that we held onto those positions... That's just a priority that we had.

Speaking for the governing board's perspective, board member Pat Reed noted:

We see that...the library, is integral to just about every single area on campus, every concept, every core subject, including electives...The [library] is integral to every area, and that's that. So how can you cut the librarians?

The participants indicated an understanding of the multiple roles of the teacher-librarian in the school. As described in Information Power: Building Partnerships for Learning (American Library Association \& Association for Education and Communications Technology, 1998), the four roles of the teacher-librarian (teacher, instructional partner, information specialist, and program manager) appear understood by stakeholders at all levels of the school district. This understanding is uncommon. Levitov (2010) states most administrators have little understanding about the roles the teacher-librarian can play in the school academic program. Attempts at educating school administrators and decision-makers about the role of the teacher-librarian are abundant in the literature (Brisco, 2003; Hartzell, 2007; Howard, 2009; McGhee \& Jansen, 2006; Nutt, 2003), which underscores the importance of Brookdale district stakeholders' understanding of the teacher-librarians' role. While this study does not attempt to demonstrate causation between understanding of teacher-librarians' role and the retention of teacher-librarians during an economic crisis, this theme is especially important to note.

\section{Implications for future research}

This case study was an attempt to uncover the decision making and rationale behind one school district's decision to retain teacher-librarians during a time of fiscal crisis. Themes based on the values and priorities of the school district were constructed through interviews and examination of documents. Additional investigation could focus on whether the values and priorities found in this case study are evident in other school districts that have chosen to retain teacher-librarians. Additionally, future research should focus on stakeholders' understanding of the role of the teacher-librarian and its impact on retention of teacher-librarian positions.

\section{Conclusion}

While teacher-librarian positions in the district were not eliminated in the latest round of cuts, it is clear that, given the state's economic problems, these positions might not be salvaged in the future. Brookdale Union High School District has always staffed its library media centers with certified, full time teacher-librarians, but administrators and the governing board know of the bleak economic picture in the coming years. The district anticipates even deeper cuts in 2010-2011 than the ones sustained in the 2009-2010 school year. When asked about the potential of eliminating teacher-librarians in the future, Dr. Jones stated,

It wouldn't be honest of me to say [teacher-librarian positions] would never be on the table. If you asked me to list five positions that I think we could cut [next year], they're not on the list. But I also can't guarantee that we're not going to have some discussion about it...The criteria we used last year hasn't changed. We still think [teacher-librarians] provide unique, valuable services that, in their absence [pauses]...I don't know what staffing at a high school looks like without a librarian in the building.

At the time of the publication of this paper, Arizona is preparing for a special election on 18 May 2010 to ask voters whether a temporary 1 cent sales tax be levied to fund public education and safety (Arizona Secretary of State, 2010). Decision-makers warn that the impact of the failure to pass Proposition 100 will result in

(C) 2010 IASL, SLAQ and therein by the authors. Diversity Challenge Resilience: School Libraries in Action Proceedings of the $12^{\text {th }}$ Biennial School Library Association of Queensland, the $39^{\text {th }}$ International Association of School Librarianship Annual Conference incorporating the $14^{\text {th }}$ International Forum on Research in School Librarianship, Brisbane QLD Australia, 27 September - 1 October 2010. 
catastrophic cuts to K-12 schools, public safety, higher education and other services. It seems a distinct possibility that teacher-librarian positions in Brookdale Union High School District hang in the balance of the election's outcome. Only time will tell whether the district will maintain certified teacher-librarians in their schools.

\section{Three key learnings:}

1. District stakeholders indicating an understanding of the teacher-librarian's role may influence the retention of teacher-librarians during an economic crisis.

2. A commitment to shared values assists in prioritizing difficult decisions.

3. Trust, transparency, and stakeholder involvement assists in prioritizing difficult decisions.

\section{References}

American Association of School Librarians (2008). The SKILLs Act. Retrieved 25 April 2010 from http://www.ala.org/ala/mgrps/divs/aasl/aaslissues/SKLLS_Act.cfm

American Libraries (2007). SKILLs Act gives high marks to school librarians. American Libraries Online. Retrieved 25 April 2010 from http://www.ala.org/ala/alonline/currentnews/newsarchive/2007/june2007/skillsact .cfm

American Library Association (2005). ALA announces new task force on school libraries. Retrieved 25 April 2010 from http://www.ala.org/ala/newspresscenter/news/pressreleases2005/july2005/taskforceschoollibrarian.cfm

American Library Association \& Association for Educational Communications and Technology (1998). Information power: Building partnerships for learning. Chicago, IL: ALA Publications.

Arizona Joint Legislative Budget Council (2010). Budget proposal. Retrieved 25 April 2010 from http://www.azleg.gov/jlbc/budgetproposal030810.pdf

Arizona Secretary of State (2010). Arizona ballot proposition guide: Proposition 100. Retrieved 25 April 2010 from http://www.azsos.gov/election/2010/May_Special/Info/PubPamphlet/english/Prop100.pdf

Asselin, M. (2002). Evidence-based practice. Teacher Librarian, 30(1), 53-54.

Braxton, B. (2003). Putting evidence-based advocacy to work. Teacher Librarian, 31(2), 41-42.

Brisco, S. (2003). Ten powerhouse strategies for educating administrators. Knowledge Quest, 32(2), 37-38.

Bush, G. (2007). Telling our school library story. Knowledge Quest, 36(1), 40-43.

Burris, M. (2006). The evolution of an advocacy group: The British Columbia coalition for school libraries. PNLA Quarterly, 70(4), 12-13.

Christensen, L. (2002). Corporate communication: The challenge of transparency. Corporate Communications: An International Journal. 7(3), 162-168.

(C) 2010 IASL, SLAQ and therein by the authors. Diversity Challenge Resilience: School Libraries in Action Proceedings of the $12^{\text {th }}$ Biennial School Library Association of Queensland, the $39^{\text {th }}$ International Association of School Librarianship Annual Conference incorporating the $14^{\text {th }}$ International Forum on Research in School Librarianship, Brisbane QLD Australia, 27 September - 1 October 2010 . 
Cotton, K., \& Wikelund, K. R. (1989). Parental involvement in education. Portland, OR: Northwest Regional Laboratory.

Denzin, N. (1984). The research act. Englewood Cliffs, NJ: Prentice Hall.

Fielding, M. (2001). Students as radical agents of change. Journal of Educational Change. 2, 123-141.

Giambra, C. (1998). "Libraries change lives": Advocacy campaign begins in New York. Emergency Librarian, 25, 18-19.

Greenwood, R. \& Hinings, C.R. (1993), Understanding strategic change: the contribution of archetypes. Academy of Management Journal, 36(5), 1052-81.

Hainer, E. (2005). Advocacy: Teacher-librarians and advocacy: Part of the problem, or part of the solution? Knowledge Quest, 33(5), 27-29.

Hartzell, G. (2007). How do decision-makers become library media advocates? Knowledge Quest, 36(1), 32-35.

Hinings, C.R., \& Greenwood, R. (1987). The normative prescription of organizations. In L.G. Zucker, (Ed.). Institutional patterns and organizations, pp. 53-70. Cambridge, MA: Ballanger Publishing.

Howard, J. K. (2009). Advocacy through relationships. School Library Monthly, 26(2), 44-45.

Kenney, B. (2008). To Spokane, with love and gratitude. School Library Journal, 54(6), 11.

Kossan, P. (2008, 11 March). Victims of school cuts: Librarians. The Arizona Republic (Phoenix, AZ), pp. A1.

Leverett, L. (2001). Extending your influence by "spreading the word". Book Report, 20(1), 24-26.

Levitov, D. (2010). Educating school administrators. School Library Monthly, 26(6), 45-47.

Loertscher, D. V., \& Todd, R. J. (2003). We boost achievement! Evidence-based practice for school library media specialists. Salt Lake City, UT: Hi Willow Research \& Publishing.

Logan, D. K. (2006). Being heard... advocacy + evidence + students = impact! School Library Media Activities Monthly, 23(1), 46-48.

McGhee, M. W., \& Jansen, B. A. (2006). The principal component: Bringing your administrator on board. Library Media Connection, 24(4), 34-35.

Nutt, P. (2003). School library media specialist/School board member: Two sides of the same coin. Knowledge Quest, 32(2), 41-42.

Patterson, J., Koenigs, A., Mohn, G., \& Rasmussen, C. (2006). Working against ourselves: Decision making in a small rural school district. Journal of Educational Administration, 44(2), 142-158.

Peterson, G., \& Short, P. (2001). The school board president's perception of the district superintendent: Applying the lenses of social influence and social style. Educational Administration Quarterly, 37(4), 533-570.

(C) 2010 IASL, SLAQ and therein by the authors. Diversity Challenge Resilience: School Libraries in Action Proceedings of the $12^{\text {th }}$ Biennial School Library Association of Queensland, the $39^{\text {th }}$ International Association of School Librarianship Annual Conference incorporating the $14^{\text {th }}$ International Forum on Research in School Librarianship, Brisbane QLD Australia, 27 September - 1 October 2010 . 
Peterson, G. \& Williams, B. (2005). The board president and superintendent: An examination of influence through the eyes of decision-makers. In Peterson, G. (Ed.). The Politics of Leadership: Superintendents and School Boards in Changing Times, pp. 23-50. Charlotte, NC: Information Age Publishing.

Russell, P. (2004). Information literacy and education policy: An instrumental case study of the Ontario public school curriculum. Unpublished masters' thesis, University of Toronto (Canada).

Schuckett, S. (2005). Be a school library advocate. Library Media Connection, 23(6), 24.

Todd, R. J. (2003). School libraries evidence: Seize the day, begin the future. Library Media Connection, 22(1), 12-18.

Todd, R. J. (2006). School libraries and evidence-based practice: An integrated approach to evidence. School Libraries Worldwide, 12(2), 31-37.

Todd, R. J. (2008a). A question of evidence. Knowledge Quest, 37(2), 16-21.

Todd, R. (2008b). The evidence-based manifesto. School Library Journal, 54(4), 38-43.

Vaill, B. (1984). The purposing of high-performing systems. In T. Sergiovanni and J. Corbally, (Eds.)

Leadership and organizational culture. (pp. 85-104). Urbana, IL: University of Illinois Press.

van Riel, C. (2000), Corporate communication orchestrated by a sustainable corporate story. In Schultz, M., Hatch, M., \& Larsen, M. (Eds). The Expressive Organization, Oxford University Press, Oxford, England, pp.157-81.

Whelan, D. (2008). Mesa (AZ) school board votes to eliminate school librarians. School Library Journal. Retrieved 25 April 2010 from http://www.schoollibraryjournal.com/article/CA6573386.html\&t=Mesa+(AZ)+Scho ol+Board+Votes+to+Eliminate+School+Librarians

Whelan, D. (2009). Washington school district eliminates middle, high school librarians. School Library Journal. Retrieved 25 April 2010 from http://www.schoollibraryjournal.com/article/CA6663004.html

Williams, J. L. (2006). Advocacy: The first step in achieving it all. Knowledge Quest, 34(3), 4-6.

Yin, R. (2008). Case study research: Design and methods (4th Ed.). Thousand Oaks, CA: Sage.

\section{Statement of Originality}

This statement certifies that the paper above is based upon original research undertaken by the author and that the paper was conceived and written by the author alone and has not been published elsewhere. All information and ideas from others is referenced.

(C) 2010 IASL, SLAQ and therein by the authors. Diversity Challenge Resilience: School Libraries in Action Proceedings of the $12^{\text {th }}$ Biennial School Library Association of Queensland, the $39^{\text {th }}$ International Association of School Librarianship Annual Conference incorporating the $14^{\text {th }}$ International Forum on Research in School Librarianship, Brisbane QLD Australia, 27 September - 1 October 2010 . 